\title{
PENGARUH PENGGUNAAN SMARTPHONE TEHADAP POLA KOMUNIKASI INTERPESONAL SISWA SMP NEGERI 50 BANDUNG
}

\author{
Pitthauly Haomasan, Nofharina \\ Mahasiswa Program Studi Ilmu Komunikasi Universitas Telkom pitthaulyh@yahoo.com/082214438883 \\ Dosen Program Studi Ilmu Komunikasi Universitas nofharina80@gmail.com/08112170170
}

\begin{abstract}
Nowadays smartphones can be consumed from young to old age. Motives teenagers in using the smartphone quite diverse, namely, the sophistication of features, fast internet access, ease of access to social media, entertainment facilities and help in doing homework. In early January 2017, SMP Negeri 50 Bandung set a ban on bringing smartphones to school, due to the recent years the influence of smartphone making problems in school. This study was conducted to find out how much the influence of using smartphones to interpersonal communication patterns of students of SMP Negeri 50 Bandung. This research is associated with Uses and Gratification theory and the method is quantitative with the type of descriptive research. This study involved one independent variable and one dependent variable. Using probability sampling method with Slovin approach with the number of respondents 82 people. Data analysis techniques used are descriptive and multiple linear regression analysis. Based on the results of simultaneous hypothesis testing, a significant influence on the use of smartphones against interpesonal communication patterns. This is evidenced by the value of F-count(41.644)> F-table (2.722) with a significance level of 5\%. The result of coefficient of determination showed that Frequency of Use, the Variety of Content and Activity give influence of 61,6\% to Interpersonal Communication Pattern of students of SMP Negeri 50 Bandung. While the action of $38.4 \%$ is the contribution of other variables that are not examined in this study. Can be concluded that SMP Negeri 50 Bandung prohibits bringing smartphones to school so obtained despite the prohibition of bringing the smartphone in effect to make high interpersonal communication patterns of students of SMP Negeri 50 Bandung.
\end{abstract}

Keywords: smartphone usage, interpersonal communication, pattern of interpersonal communication, uses and gratification.

\begin{abstract}
ABSTRAK
Dewasa ini smartphone bisa dikonsumsi dari usia muda hingga tua. Motif remaja dalam menggunakan smartphone cukup beragam, antara lain karena kecanggihan fitur, akses internet yang cepat, kemudahan dalam mengakses sosial media, sarana hiburan dan membantu dalam mengerjakan tugas sekolah. Pada awal januari 2017 ditetapkan larangan membawa smartphone di SMP Negeri 50 Bandung, dikarenakan beberapa tahun belakangan pengaruh smartphone membuat pemasalahan disekolah. Penelitian ini dilakukan untuk mengetahui seberapa besar pengaruh penggunaan smartphone terhadap pola komunikasi interpersonal siswa SMP Negeri 50 Bandung. Penelitian ini dikaitkan dengan teori Uses and Gratification. Metode yang digukakan ialah kuantitatif dengan jenis penelitian deskriptif. Penelitian ini melibatkan satu variabel independen dan satu variabel dependen. Pengambilan sampel menggunakan rumus probability Sampling dengan pendekatan Slovin dengan jumlah responden 82 orang. Teknik analisis data yang digunakan adalah deskriptif dan analisis regresi linear berganda. Berdasarkan hasil pengujian hipotesis secara simultan, adanya pengaruh yang signifikan dari penggunaan smartphone terhadap pola komunikasi interpesonal. Hal ini dibuktikan dengan nilai $F$ hitung $(41,644)>F$ tabel $(2,722)$ dengan tingkat signifikasinya 5\%. Berdasarkan uji hipotesis secara parsial, didapat bahwa frekuensi penggunaan, macam isi dan aktivitas berpengaruh signifikan terhadap
\end{abstract}


pola komunikasi interpersonal siswa SMP Negeri 50 Bandung. Berdasakan koefisien determinasi didapat bahwa variabel Frekuensi Penggunaan, Macam Isi dan Aktivitas memberikan pengaruh sebesar 61,6\% terhadap Pola Komunikasi Interpersonal Siswa SMP Negeri 50 Bandung. Sedangkan sisanya sebesar 38,4\% merupakan kontribusi variabel lain yang tidak diteliti pada penelitian ini. Dapat disimpulkan bahwa SMP Negeri 50 Bandung melarang membawa smartphone ke sekolah sehingga dari penelitian ini diperoleh walaupun larangan membawa smartphone diberlakukan membuat tingginya pola komunikasi interpersonal siswa SMP Negeri 50 Bandung.

Kata kunci : penggunaan smartphone, komunikasi interpesonal, pola komunikasi interpersonal, uses and gratificaiton

\section{PENDAHULUAN}

SMP Negeri 50 Bandung adalah sekolah menengah pertama negeri yang berada di Kota Bandung, Jawa Barat, Indonesia. Sekolah ini berlokasi di Jalan Pasirjati No. 12, Kelurahan Cigending, Kecamatan Ujungberung, Kota Bandung. Masa pendidikan di SMP Negeri 50 Bandung ditempuh dalam waktu tiga tahun pelajaran, mulai dari kelas VII hingga kelas IX, seperti pada umumnya masa pendidikan sekolah menengah pertama di Indonesia. Pada awal Januari 2017, SMP Negeri 50 Bandung menetapkan peraturan larangan membawa smartphone ke sekolah. Dibeberapa sekolah memang diperbolehkan untuk membawa telepon genggam dengan berbagai alasan. Peristiwa ini tentu memiliki pro dan kontra dari berbagai pihak, namun tergantung pada ketetapan sekolah masing-masing. Dengan diperbolehkannya siswa membawa telepon pintar yang tidak hanya berfungsi sebagai alat telepon atau sms dengan berbagai fitur akan memiliki dampak bagi siswa yang menggunkannya disekolah. Keputusan tersebut diambil setelah tim guru melakukan rapat berserta kepala sekolah, dimana belakangan kerap terjadi hambatan ketika proses belajar mengajar karena siswa tidak fokus, ketika istirahat para siswa tidak saling membaur dan asyik dengan telepon pintar masing-masing.

Menurut McLuhan (dalam Morissan, dkk, 2010: 31), teknologi komunikasi menjadi penyebab utama perubahan budaya. Kehidupan keluarga, lingkungan kerja, sekolah, pertemanan, kegiatan keagamaan, politik, dan sebagainya semua terpengaruh teknologi komunikasi. Interaksi manusia dengan manusia telah digantikan menjadi interaksi manusia dengan teknologi dan seringkali tidak kita sadari teknologi dapat mengurangi interaksi seseorang secara langsung dengan orangorang terdekat yang ada di sekitar misalnya antara teman satu sekolah karena sibuk dengan gadgetnya. Saling tegur sapa dengan menghadapkan senyum pada teman atau guru semakin berkurang, malahan sibuk sendiri di hadapan telepon pintar sudah dianggap lumrah di masyarakat saat ini.

Pola komunikasi interpersonal mengacu kepada bentuk yang menggambarkan cara berkomunikasi di antara dua individu secara langsung dan memiliki efek pada masing masing individu. Menurut onlinesense.org/ phubbing (diakses 12 Desember 2017), 
sebanyak $87 \%$ remaja memilih untuk berkomunikasi lewat smartphone dibading melakukan komunikasi tatap muka dengan satu dan lainnya. Ini menunjukkan terdapat fenomena phubbing pada remaja saat ini. Hal tersebut akan mempengaruhi pola komunikasi interpersonal pada siswa. Penggunaan smartphone yang semakin berkembang di kalangan remaja ini, menimbulkan berbagai macam perubahan sikap dan perilaku di kalangan remaja itu sendiri.

\section{TINJAUAN PUSTAKA}

\section{Komunikasi Interpersonal}

Agus (dalam Suranto, 2011: 13) mengemukakan bahwa komunikasi interpersonal adalah interaksi tatap muka antar dua atau beberapa orang, di mana pengirim dapat menyampaikan pesan secara langsung dan penerima pesan dapat menerima dan menanggapi secara langsung pula. Mulyana (2010:81) menyatakan bahwa komunikasi interpersonal atau komunikasi antarpribadi adalah komunikasi antara orang-orang secara tatap muka, yang memungkinkan setiap pesertanya menangkap reaksi orang lain secara langsung, baik secara verbal maupun non verbal.

Dari pendapat para ahli diatas, dapat disimpulkan bahwa komunikasi interpersonal merupakan penyampaian pesan antar pribadi secara tatap muka yang memiliki efek dan umpan balik.

\section{Klasifikasi Komunikasi Interpersonal}

Redding pada Komunikasi Organisasi karya Muhammad (2014: 159-160) mengembangkan klasifikasi komunikasi interpersonal menjadi beberapa macam, diantaranya:

a. Interaksi Intim

Interaksi intim yaitu komunikasi dengan teman baik, pasangan yang sudah menikah, anggota famili, dan orang-orang yang mempunyai ikatan emosional yang kuat. Kekuatan dari hubungan menentukan iklim interaksi yang terjadi.

b. Percakapan Sosial

Percakapan sosial adalah interaksi untuk menyenangkan seseorang secara sederhana dengan sedikit berbicara. Percakapan biasanya tidak begitu terlihat secara mendalam.

c. Interograsi atau Pemeriksaan

Interograsi atau pemeriksaan adalah interaksi antara seseorang yang ada dalam kontrol, yang meminta atau bahkan menuntut informasi daripada yang lain.

d. Wawancara

Wawancara adalah satu bentuk komunikasi interpersonal di mana dua orang terlibat dalam percakapan yang berupa tanya jawab. Salah seorang mengajukan pertanyaan untuk mendapatkan informasi dan yang lainnya mendengarkan dengan baik kemudian memberikan jawaban yang dikehendaki sampai tujuan wawancara tercapai.

\section{Uses and Gratifications}

Teori komunikasi yang digunakan dalam 
penelitian ini menggunakan model komunikasi Uses and Gratifications. Audience memilih media apa yang akan hendak digunakan untuk memenuhi kebutuhan dan keinginannya, lalu memilih juga pesan apa yang hendak dikonsumsi.

Teori ini berpusat pada penggunaan media untuk mendapatkan suatu kepuasan atas kebutuhannya. Media berperan pasif sedangkan audience berperan aktif dalam menentukan media apa untuk memuaskan kebutuhan dan berdampak bagi penggunanya.

Katz, Blumer \& Gurevitch menjelaskan mengenai asumsi dasar dari teori Uses and Gratificaitons, yaitu :

a. Khayalak dianggap aktif, artinya khayalak sebagai bagian penting dari penggunaan media massa diamsumsikan mempunyai tujuan.

b. Dalam proses komunikasi massa, inisiatif untuk mengaitkan pemuasan kebutuhan dengan pemilihan media terletak pada khayalak.

c. Media massa harus bersaing dengan sumber-sumber lain untuk memuaskan kebutuhannya. Kebutuhan yang dipenuhi media lebih luas. Bagaimana kebutuhan ini terpenuhi melalui konsumsi media amat bergantung pada perilaku yang bersangkutan.

d. Tujuan pemilih media massa disimpulkan dari data yang diberikan anggota khayalak. Artinya, orang dianggap cukup mengerti untuk melaporkan kepentingan dan motif pada situasi- situasi tertentu. e. Penilaian tentang arti kultural dari media massa harus ditangguhkan sebelum diteliti lebih dahulu orientasi khayalak

\section{METODE PENELITIAN}

Pada penelitian ini menggunakan metode kuantitatif dengan tipe penelitian survei deskriptif. Penelitian deskriptif bertujuan menggambarakan secara tepat sifatsifat suatu individu, keadaan, gejala atau kelompok tertentu atau menentukan frekuensi atau penyebaran suatu gejala yang ada hubungannya antara suatu gejala dan gejala lainnya dalam masyarakat (Bajari, 2015:36).

Penelitian deskriptif melakukan analisis hanya sampai deskripsi, yaitu menganalisis dan menyajikan fakta secara sistematik sehingga dapat lebih mudah dipahami dan disimpulkan. Kesimpulannya memiliki dasar faktual yang jelas sehingga dapat dikembalikan langsung pada data yang diperoleh. Uraian kesimpulan didasari oleh angka yang tidak diolah secara mendalam. Pada umumnya pengolahan datanya didasarkan pada analisis persentase dan analisis kecenderungan (Abidin, 2015:28).

Sugiyono (2014:81) menyimpulkan bahwa metode penelitian survei adalah metode penelitian kuantitatif yang digunakan untuk mendapatkan data yang terjadi pada masa lampau atau saat ini, tentang keyakinan, pendapat, karakteristik, perilaku, hubungan variabel dan untuk menguji beberapa hipotesis tentang variabel sosiologis dan psikologis dari sampel yang diambil dari populasi tertentu, teknik pengumpulan data dengan pengamatan (wawancara atau kuesioner) yang tidak 
mendalam, dan hasil penelitian cenderung untukdi generalisasikan.

\section{HASIL DAN PEMBAHASAN}

\section{a. Analisis Deskriptif Penggunaan Smartphone}

Seluruh siswa kelas XI SMP Negeri 50 Bandung sudah memiliki smartphone, dimana pemakaian teknologi tersebut tentu memiliki pengaruh. Umur siswa kelas XI SMP Negeri 50 Bandung rata rata 14 tahun yang di kategorikan remaja menurut menurut Peraturan Menteri Kesehatan RI Nomor 25 tahun 2014 (www. depkes.go.id, diakses 8 Desember 2017). Masa remaja merupakan suatu periode penting dari rentan kehidupan, suatu periode transisional, masa perubahan, masa usia bermasalah, masa dimana individu mencari identitas diri, usia menyeramkan, masa unrealism, dan ambang menuju kedewasaan (Krori, 2011).

Secara keseluruhan hasil tanggapan responden dan nilai presentasi yang didapatkan mengenai variabel penggunaan smartphone sebesar 74\%. Nilai presentase tanggapan responden mengenai variabel penggunaan smartphone berada pada interval 62,50\%-81,25\% dengan kategori tinggi. Berdasarkan hasil tanggapan responden dan nilai persentase yang didapatkan, penggunaan smartphone dianggap memenuhi tiga dimensi penggunaan smartphone pada siswa SMP Negeri 50 Bandung dianggap memenuhi tiga indikator dari penggunaan smartphone. Indikator Frekuensi Penggunaan memiliki skor 533 tau $81,3 \%$ berada pada kategori sangat baik, selanjutnya Macam Isi mendapat skor 487 atau 74,2\% dengan kategori baik dan indikator Aktvitas memiliki skor 1891 atau $72,1 \%$ dengan kategori baik.

\section{b. Analisis Deskriptif Pola Komunikasi Interpersonal}

Redding pada Komunikasi Organisasi karya Muhammad (2014: 159-160) mengembangkan klasifikasi komunikasi interpersonal menjadi beberapa macam yakni interaksi intim, percakapan sosial, interogasi atau pemeriksaan dan wawancara. Keempat komponen tersebut dikembangkan menjadi 7 pernyataan dan disebakan kepada 82 responden dengan karakteristik yang telah ditentukan oleh peneliti. Hasil perhitungan tanggapan respoden mengenai variabel pola komunikasi interpersonal memiliki rata-rata nilai presentase yang termasuk dalam kategori tinggi. Dari 7 pernyataanpadakuesionermegenaivariabelpola komunikasi interpersonal. Hasil perhitungan akumulasi tanggapan responden mengenai variabel pola komunikasi interpersonal adalah 1819 atau 79,2\%. Nilai persentase tanggapan responden megenai variabel $Y$ tersebut berada pada interval $62,50 \%-81,25 \%$ dengan kategori tinggi.

Berdasarkan hasil tanggapan responden dan nilai persentase yang didapatkan, pola komunikasi interpersonal siswa SMP Negeri 50 Bandung dianggap telah memenuhi 4 dimensi dari pola komunikasi interpersonal. Pertama, interaksi intim pada responden yang artinya ada komunikasi interpersonal dengan teman sekelasnya. Kedua, percakapan sosial pada responden yang membuat responden senang untuk berbicara tatap muka secara 
langsung. Ketiga, interogasi atau pemeriksaan yang artinya responden melakukan pemastian dengan komunikasi terhadap suatu hal dan keempat, melakukan tanya jawab dimana responden senang dengan adanya dikusi mengenai permasalahannya.

\section{c. Pengaruh Penggunaan Smartphone Terhadap Pola Komunikasi Interpersonal}

Setelah menghitung tanggapan responden dilakukan perhitungan statistik menggunakan analisis regresi linear berganda, persamaan yang diperoleh adalah $\mathrm{Y}=0,764+0,261 \mathrm{X} 1+0,227 \mathrm{X} 2+0,327 \mathrm{X} 3$ dan persamaan tersebut artinya, jika variabel Pola Komunikasi Interpersonal (Y) Siswa SMP Negeri 50 Bandung tidak dipengaruhi oleh ketiga variabel bebasnya yaitu Frekuensi Penggunaan $\left(\mathrm{X}_{1}\right)$,Macam Isi $\left(\mathrm{X}_{2}\right)$ dan Aktivitas $\left(\mathrm{X}_{3}\right)$ bernilai nol, maka besarnya rata-rata Pola Komunikasi Interpersonal akan bernilai 0,764. Koefisien regresi variabel $X_{1}$ sebesar 0,261 . Koefisien regresi variabel $X_{2}$ sebesar 0,227. Koefisien regresi variabel $\mathrm{X}_{3}$ sebesar 0,327.

Selanjutnya peneliti melakukan Uji Hipotess dengan menggunakan Uji F, diperoleh nilai $\mathrm{F}$ hitung sebesar 41,644. Karena nilai $\mathrm{F}$ hitung $(41,644)>\mathrm{F}$ tabel $(2,722)$, maka $\mathrm{H}_{0}$ ditolak. Dengan demikian dapat disimpulkan bahwa secara simultan terdapat pengaruh yang signifikan dari Frekuensi Penggunaan $\left(\mathrm{X}_{1}\right)$, Macam Isi $\left(\mathrm{X}_{2}\right)$ dan Aktivitas $\left(\mathrm{X}_{3}\right)$ terhadap Pola Komunikasi Interpersonal (Y) Siswa SMP Negeri 50 Bandung.

Berikutnya, uji $\mathrm{T}$ variabel $\mathrm{X}_{1}$ memiliki nilai $\mathrm{t}$ hitung lebih besar dari nilai t tabel. Karena nilai t hitung $(2,518)>t$ tabel $(1,991)$, oleh karena itu dapat disimpulkan bahwa secara parsial terdapat pengaruh signifikan dari Frekuensi Penggunaan $\left(\mathrm{X}_{1}\right)$ terhadap Pola Komunikasi Interpersonal (Y) Siswa SMP Negeri 50 Bandung. Variabel $\mathrm{X}_{2}$ memiliki nilai t hitung lebih besar dari nilai t tabel. Karena nilai $\mathrm{t}$ hitung $(2,418)>\mathrm{t}$ tabel $(1,991)$, oleh karena itu dapat disimpulkan bahwa secara parsial terdapat pengaruh signifikan dari Macam Isi $\left(\mathrm{X}_{2}\right)$ terhadap Pola Komunikasi Interpersonal (Y) Siswa SMP Negeri 50 Bandung. Variabel $\mathrm{X}_{3}$ memiliki nilai t hitung lebih besar dari nilai $\mathrm{t}$ tabel. Karena nilai $\mathrm{t}$ hitung $(3,119)>\mathrm{t}$ tabel $(1,991)$, oleh karena itu dapat disimpulkan bahwa secara parsial terdapat pengaruh signifikan dari Aktivitas $\left(\mathrm{X}_{3}\right)$ terhadap Pola Komunikasi Interpersonal (Y) Siswa SMP Negeri 50 Bandung.

\section{KESIMPULAN}

Berdasarkan hasil penelitian mengenai Pengaruh Penggunaan Smartphone Terhadap Pola Komunikasi Interpersonal Siswa SMP Negeri 50 Bandung dapat ditarik kesimpulan bahwa ada pengaruh yang signifikan dari penggunaan smartphone terhadap pola komunikasi interpersonal siswa SMP Negeri 50 Bandung sudah baik. Pola komunikasi interpersonal dipengaruhi terhadap penggunaan smartphone. SMP Negeri 50 Bandung melarang membawa smartphone ke sekolah sehingga dari penelitian ini diperoleh walaupun larangan membawa smartphone diberlakukan sehingga siswa menggunakan smartphone 
hanya diluar jam sekolah membuat tingginya pola komunikasi interpersonal siswa SMP Negeri 50 Bandung.

Indikator penggnaan smartphone memiliki pengaruh sebesar $61,6 \%$ terhadap Pola Komunikasi Interpersonal Siswa SMP Negeri 50 Bandung. Sedangkan sisanya sebesar 38,4\% merupakan kontribusi variabel lain yang tidak diteliti pada penelitian ini.

\section{DAFTAR PUSTAKA}

Abidin, Yusuf Zainal. (2015). Manajemen Komunikasi: Filosofi, Konsep, dan Aplikasi.
Bandung: Pustaka Setia

Arni Muhammad. (2014). Komunikasi Organisasi. Jakarta: Bumi Aksara

AW Suranto. (2011). Komunikasi Interpersonal. Yogyakarta: Graha Ilmu

Morissan, Andy Corry Wardhani \& Farid Hamid. (2010). Teori Komunikasi Massa. Bogor: Ghalia Indonesia.

Mulyana, Deddy. (2010). Ilmu Komunikasi Suatu Pengantar. Cetakan Ke-14. Bandung: PT Remaja Rosdakarya

Sugiyono. (2012). Metode Penelitian Pendidikan. Bandung : Alfabeta. 